\title{
Marek Czyżewski
}

\section{Repatrianci i wypędzeni: wzajemne uprzedzenia w relacjach biograficznych}

\section{Empiryczny punkt wyjścia}

Punktem wyjścia tego artykułu jest wybrany wywiad narracyjny, dotyczący polskich doświadczeń wojennych ${ }^{1}$. Narratorka, p. Zofia relacjonuje swoje doświadczenia młodej dziewczyny, która przeżyła II wojnę światową w Wilnie. Moją szczególną uwagę zwróciły fragmenty wywiadu dotyczące pierwszego okresu pobytu narratorki na Warmii i Mazurach w wyniku tzw. repatriacji w 1945 r., w tym zwłaszcza - obarczone silną negatywną konotacją - dwie krótkie wypowiedzi o mazurskich kobietach. W relacji pani Zofii mazurskie kobiety (określane jako „Niemki” - do tej sprawy jeszcze powrócę) przedstawiają się następująco:

No poza tym cóż. Niemki na mnie robiły bardzo yy takie dziwne wrażenie. One były takie pokorne, wystarczyło tupnąć nogą. Ona właściwie skłonna była podporządkować się każdemu życzeniu (19:30-32)².

I tam na przykład wszyscy ci ubowcy to każdy z nich, oni mieli w domu, prowadziły im te te gospodarstwa. Ale nie tylko, bo one po prostu służyły wszelkim celom. Tak, że to, to było też takie bardzo przykre (19:33-20:1).

W przytoczonych wypowiedziach pojawiają się liczne tekstowe formy stereotypizacji: zastosowanie liczby mnogiej do odpowiednich kategoryzacji i czynności, a także uogólnienia „wszyscy” i „każdy”. W obrębie zgeneralizowanego obrazu relacji między mazurskimi kobietami a „ubowcami” pojawia się wprawdzie jedno sformułowanie w liczbie pojedynczej („Ona właściwie skłonna była podporządkować się każdemu życzeniu"), lecz sformułowanie to odnosi się do

1 Artykuł stanowi wersję fragmentu raportu opracowanego w ramach projektu KBN Biografia a tożsamość narodowa (Czyżewski 1995). Raport ten dotyczył relacji między trajektorią (cierpieniem, zagrożeniem) a uprzedzeniem w polskich doświadczeniach wojennych.

2 Liczby w nawiasach oznaczają kolejno odpowiednią stronę i linijkę, z których pochodzi dany cytat lub omawiany fragment wywiadu. $\mathrm{Z}$ powodu braku miejsca nie było możliwe zamieszczenie integralnego tekstu wywiadu. Wspomniane liczby nie mogą tu zatem odsyłać do lektury wywiadu, lecz ułatwiają czytelnikowi orientację w jego przebiegu (wskazują na to, co zostało w wywiadzie powiedziane wcześniej, a co później). 
wyobrażenia prototypowej reprezentantki omawianej grupy (,ona”) i - tym samym - funkcjonuje jako dogodna platforma dla konstrukcji stereotypu ${ }^{3}$.

W cytowanych wypowiedziach obecne są także dalsze warstwy znaczeniowe, a mianowicie „etnizacja” i „polityzacja” omawianych kategorii społecznych: mężczyźni to „ubowcy”, reprezentanci proradzieckiej komunistycznej władzy, kobiety to Mazurki, reprezentantki lokalnej (lub niemieckiej) ludności. „Etnizacja" dyskursu to kolejny silny marker wyrażeń stereotypowych.

$\mathrm{Na}$ uwagę zasługuje przemilczenie, a tym samym pewne napięcie w obrębie całościowej argumentacji: ubowcy „mający” kobiety mazurskie w domu to Polacy. W omawianej wypowiedzi - w odróżnieniu od innych fragmentów wywiadu - ubowcy nie są przedstawiani w kategoriach etnicznych, lecz wyłącznie jako reprezentanci władzy komunistycznej.

Wreszcie, przytoczone wypowiedzi zawierają uprzedzeniową degradację kobiet mazurskich - kobiety te miałyby się charakteryzować nieusprawiedliwioną uległością seksualną. Samo sformułowanie tego zarzutu jest zawoalowane: „pokorne”, „skłonne podporządkować się każdemu życzeniu”. Seksualny charakter uległości jest jednak oczywisty, gdyż na wyobrażenie o uległości osoby służącej wobec swojego pana nałożone jest wyobrażenie o uległości kobiety wobec mężczyzny: mężczyzni „mieli” kobiety „, domu”, kobiety „,prowadziły im gospodarstwa” i „służyły wszelkim celom”.

\section{Trajektoria a uprzedzenie}

Do dalszej analizy cytowanych wypowiedzi wracam poniżej, uwzględniając szersze fragmenty wywiadu. W tym miejscu chciałbym zdać sprawę z powodów mojego badawczego zainteresowania.

Cytowane wypowiedzi odnoszą się do szerszego zagadnienia relacji między trajektorią a uprzedzeniem. Trajektorię rozumiem - za Fritzem Schütze - jako jedną z podstawowych struktur doświadczenia biograficznego, a mianowicie taką, która spełnia następujące dwie cechy:

a) narrator podlega zewnętrznym, przymusowym okolicznościom, na które nie ma wpływu (np. prześladowanie, uwięzienie, zsyłka, choroba) oraz

b) zasadzie podlegania zewnętrznym okolicznościom towarzyszy cierpienie narratora (Schütze 1981, 1982, 1989, 1992). Cierpienie narratora wynika nie tylko z konkretnych negatywnych doświadczeń (jak ból, głód, wyczerpanie, lęk $\mathrm{i}$ inne), lecz także z postrzeganego przez narratora braku możliwości zmiany zewnętrznych okoliczności.

Trzeba podkreślić, że trajektorię traktuję przede wszystkim jako strukturę dyskursową, to znaczy jestem zainteresowany przede wszystkim tym, jak ludzie opowiadają swoje życie w kategoriach trajektorii. Poprzez „dyskursowe” rozumienie trajektorii nie chcę bynajmniej sugerować swojej niewiary w szczerość

${ }^{3}$ O relacji prototypu do stereotypu pisał u nas A.P. Wejland (1991). 
narratorów lub podważać prawomocności wywiadu narracyjnego jako techniki umożliwiającej wgląd w realne, „ówczesne” doświadczenia biograficzne. Położenie nacisku na trajektorię jako - także - pewien sposób organizacji narracyjnej jest raczej świadectwem przekonania o potrzebie uwzględnienia specyfiki mowy - w tym zwłaszcza wzorów narracji i argumentacji - jako społecznej formy przekazywania doświadczeń biograficznych.

W podobny sposób - jako strukturę dyskursową - traktuję także zjawisko uprzedzenia. W tym miejscu niezbędne jest dodatkowe objaśnienie. W obszernej i wielorodnej tradycji badań nad stereotypami i uprzedzeniami ugruntowały się dwa główne kierunki. Podejście psychodynamiczne określało uprzedzenie jako negatywne emocjonalne nastawienie (Adorno i in. 1950; Allport 1954), uznając zjawisko uprzedzenia za pewnego rodzaju - socjalizacyjnie uwarunkowaną - patologię psychologiczną. Podejście poznawcze określało uprzedzenie jako odporny na modyfikacje schemat poznawczy, uznając uprzedzenia za funkcjonalnie niezbędne - tak dla indywidualnych procesów poznawczych, jak i dla relacji społecznych (dla formowania tożsamości grupowej i dla społecznego uwzorowania konfliktów międzygrupowych, np. Tajfel 1982, a także w dużej mierze Bar-Tal $\mathrm{i}$ in. 1989).

W ciągu ostatnich dziesięciu lat kształtuje się trzecie podejście do zagadnienia stereotypów i uprzedzeń, w myśl którego stereotypy i uprzedzenia należy traktować jako specyficzne struktury komunikowania się, jako struktury dyskursu, w szczególności - jako specyficzne formy opowiadania i argumentacji (Billig i in. 1988; Billig 1991; van Dijk 1984, 1992, 1993; Wodak i in. 1990, 1994). „Język” sterotypów i uprzedzeń jest - zgodnie z tą, bliską mi perspektywą - pewnego rodzaju zniekształceniem potencjalnych możliwości ludzkiej komunikacji i winien podlegać nie tylko analizie, lecz także krytyce. Proponuję nazwać to podejście podejściem retorycznym ${ }^{4}$.

Przyjmując przedstawione ustalenia pojęciowe trzeba powiedzieć, że „typowe" stereotypy innych grup etnicznych i uprzedzenia wobec nich - w tym także stereotypy i uprzedzenia w polskich doświadczeniach wojennych - wiążą się zazwyczaj z doświadczeniem indywidualnej lub kolektywnej trajektorii, postrzeganej jako cierpienia wynikające $\mathrm{z}$ działalności owych innych, wrogich grup etnicznych (przykładem są tu polskie stereotypy i uprzedzenia wobec Rosjan i Niemców). Można powiedzieć, że owe „typowe” stereotypy i uprzedzenia są dyskursowo „umotywowane": można bowiem bez trudu wskazać, czemu dany stereotyp lub uprzedzenie miałyby „służyć” w obrębie komunikacyjnego systemu orientacji danej osoby. Innymi słowy, w typowych przypadkach można łatwo odpowiedzieć na pytanie, jaką funkcję lub dysfunkcję w ogólnym komunikacyjnym systemie orientacji danej osoby pełni dany stereotyp lub uprzedzenie: na przykład uprzedzeniowy obraz Niemców lub Rosjan jako narodów zbrodniczych

${ }^{4}$ Dalsze omówienie retorycznego pojęcia uprzedzenia zawiera mój raport badawczy (Czyżewski 1995). 
służył z pewnością konsolidacji tożsamości grupowej Polaków w obliczu zagrożenia. Podkreślmy na marginesie: chodzi tu o dyskursowe - a nie psychologiczne - funkcje lub dysfunkcje wewnętrzne, to znaczy funkcje na rzecz własnego systemu komunikacyjnego; uprzedzeniowy system orientacji jest zazwyczaj - prócz niektórych sytuacji wojny i zagrożenia, gdzie może służyć na przykład obronnej mobilizacji - dysfunkcjonalny zewnętrznie, jako wadliwy lub konfliktogenny system orientacji w otoczeniu.

Wypowiedzi pani Zofii mogłyby - pozornie - wskazywać na „nieumotywowane" uprzedzenie - „nieumotywowane" w tym sensie, że na pierwszy rzut oka trudno wskazać, czemu to uprzedzenie miałoby „służyć” w obrębie komunikacyjnego systemu orientacji narratorki. Polacy nie uważają przecież, iżby ucierpieli w czasie wojny bezpośrednio od Mazurów. Mazurzy formalnie, co prawda, obywatele Trzeciej Rzeszy, w oczach Polaków w dużym stopniu byli jednak ludnością lokalną. Ponadto indywidualna i kolektywna trajektoria narratorki jako repatriantki także nie ma - ani rzeczywistego, ani dyskursowego - powiązania z postępowaniem Mazurów, lecz z utratą wileńskiej ojczyzny na rzecz Związku Radzieckiego.

Istniały jednakże szczególne historyczne uwarunkowania, które mogły skłaniać polskich repatriantów i Mazurów (a także Ślązaków i pozostałych tzw. wypędzonych) do obopólnej niechęci.

\section{Repatrianci i wypędzeni: historyczne uwarunkowania niechęci}

Obydwie grupy nie były, co prawda, wobec siebie stronami wojny, lecz znalazły się w wyniku wojny w sytuacji nieuniknionego konfliktu o ziemię, miejsce zamieszkania i dobytek. Sytuacja konfliktu międzygrupowego prowadzi często do powstawania i umacniania się wzajemnych stereotypów i uprzedzeń. Mechanizm ten opisany został w tzw. teoriach konfliktu w dziedzinie stereotypów i uprzedzeń (Stroebe, Insko 1989: 14-15). W przypadku repatriantow i wypędzonych można mówić o konkurencji zarówno o zasoby materialne, jak i niematerialne w odczuciu wypędzonych polscy repatrianci zabierali im ich ojczyznę. Za sprawą tzw. szabrowników przybywających z centralnej Polski konflikt ten przyjmował często postać przestępczego zagrożenia, a także upokarzające dla lokalnej ludności formy. Negatywny wizerunek polskich szabrowników podlegał stereotypowej generalizacji, obejmował także repatriantów i Polaków w ogóle. Zebrane w Niemczech po wojnie wspomnienia wypędzonych zawierają świadectwa tego zjawiska ${ }^{5}$.

5 Por. obszerne dokumentacje niemieckie na temat tzw. „wypędzenia” ludności niemieckiej z terenów na wschód od Odry i Nysy, opatrzone licznymi dokumentami osobistymi (Die Vertreibung 1984; Vertreibung... 1989). 
Dodać należy, że liczne struktury uprzedzeniowe pod adresem Polaków zawarte w języku wspomnianych dokumentacji niemieckich układają się w następujący wzór: Polacy przybywają z pustymi rękoma, są cywilizacyjnie niżsi, zabierają nam nasze gospodarstwa, inwentarz, dobytek i domy, dewastują rezultaty naszej pracy. Trudno oprzeć się wrażeniu, że wizerunek ten zbliżony jest do współczesnego obrazu tzw. azylantów w Niemczech i tym samym stanowił przypuszczalnie - do pewnego stopnia - jego historyczny pierwowzór. Istotną różnicę stanowi element do tej pory pominięty: wypędzeni wspominają $\mathrm{z}$ oburzeniem graniczącym z nienawiścią, że Polacy zmuszali ich do ciężkiej, niewolniczej pracy i nie godzą się na to, by grupa postrzegana jako cywilizacyjnie niższa zajmowała wobec nich dominującą pozycję.

Interesująca niespójność odnosi się do wizerunku Rosjan i Polaków w oczach wypędzonych. Rosjanie to żołnierze Armii Czerwonej, którzy przynoszą bezpośrednie zagrożenie i okrutny terror (m.in. w postaci masowych gwałtów na kobietach - do tego tematu jeszcze powrócę), lecz mimo to nie są oni obiektem takiej nienawiści jak Polacy. Rosjanie są wprawdzie - podobnie jak Polacy - postrzegani jako ludzie cywilizacyjnie niżsi (co w odniesieniu do postępowania żołnierzy radzieckich związane jest $\mathrm{z}$ toposem nieopanowanej dzikości), ale w innym istotnym wymiarze Rosjanie stoją na tym samym poziomie co ludność niemiecka: są widziani jako reprezentanci wojennego wroga. Do obrazu wroga wojennego należy symetryczność relacji: w czasie wojny każda ze stron może być zwycięzcą (jak Niemcy w trakcie agresji na Związek Radziecki) lub przegranym (jak Niemcy pod koniec wojny). Ponadto do upowszechnionego obrazu wojny należy także rejestr nieuniknionych cierpień, w tym także terror wobec ludności cywilnej. Zauważyć trzeba, że z perspektywy wypędzonych - i ogólnie, z niemieckiej perspektywy Polacy rzadko byli i są postrzegani jako równoprawny wojenny przeciwnik w ramach II wojny światowej i na przestrzeni dziejów. Dodajmy, że odmowa partnerskiej percepcji Polski i Polaków ze strony Niemców odnosi się także do szeregu innych zagadnień politycznych, kulturowych i gospodarczych. W tym względzie perspektywa polska jest dramatycznie odmienna. Reperkusje tych różnic we wzajemnym postrzeganiu widoczne były na forum publicznym m. in. w 1995 roku, gdy okazało się, że władze niemieckie nie zamierzają zaprosić prezydenta Polski (był nim wówczas Lech Wałęsa) na obchody pięćdziesiątej rocznicy zakończenia wojny w Berlinie.

Uprzedzenia wypędzonych wobec Polaków są zatem w świetle ich historycznych uwarunkowań zrozumiałe - co nie oznacza, że usprawiedliwione. Szczególnie skutecznym czynnikiem wzmacniającym struktury uprzedzeniowe było w tym wypadku - niejednokrotnie uzasadnione - postrzeganie samego siebie w kategoriach ofiary konfliktu, w kategoriach trajektorii indywidualnej i kolektywnej. W kontekście zasięgu i intensywności struktur uprzedzeniowych we wspomnieniach wypędzonych przydarzające się rzadko uprzedzeniowe wypowiedzi repatriantów o wypędzonych - w tym wypowiedzi pani Zofii o mazurskich 
kobietach - sprawiają wrażenie błahych lapsusów językowych. A jednak warto się dłużej nad nimi zatrzymać. Po pierwsze dlatego, że zjawiska tego nie sposób - jak wskazywałem - wyjaśnić przez związek z trajektorią, a wspomniane teorie konfliktu udzielają tu niepełnej odpowiedzi. Oznaki niechęci repatriantów wobec wypędzonych - skądinąd względnie słabo widoczne w kontekście dominujących rysów obojętności bądź współczucia - dają się bowiem jedynie częściowo objaśnić przez wymóg uzasadnienia własnego zachowania lub własnej grupy etnicznej w konflikcie (zaboru mienia i pozbawienia ojczyzny). Pojawia się zatem pytanie o inne mechanizmy „motywujące” uprzedzenie, czyli odpowiadające za pojawianie się elementów struktur uprzedzeniowych w konkretnych wypowiedziach. Po drugie, kieruję się tu postulatem, by relacje między grupami etnicznymi rozpatrywać krytycznie, co oznacza także potrzebę wykroczenia poza schematy własnej grupy etnicznej w postrzeganiu historii ${ }^{6}$. Należy dodać, że krytyczna analiza stereotypów i uprzedzeń w narracji biograficznej o wydarzeniach historycznych nie ma charakteru personalnego, gdyż nie dotyczy indywidualnych cech psychologicznych, lecz przejawiających się w relacjach biograficznych anonimowych mechanizmów tekstowych, socjologicznych lub psychospołecznych, będących ze swej istoty własnością zbiorową.

\section{Granice współczucia}

Cytowane niechętne wypowiedzi pani Zofii o kobietach mazurskich stanowiły dla mnie zagadkę z uwagi na kontrast między tymi wypowiedziami a wiedzą o historycznych okolicznościach 1945 r., w tym zwłaszcza o terrorze wobec niemieckiej ludności cywilnej ze strony żołnierzy Armii Czerwonej. Istotną częścią tego terroru były masowe, często niezwykle bestialskie gwałty na niemieckich kobietach. Uwzględniając jedynie tzw. byłe wschodnie tereny Niemiec historycy szacują liczbę ofiar tej fali gwałtów na co najmniej dwa miliony, przy czym wiele kobiet padło ofiarą gwałtu wielokrotnie. Gwałty połączone były często z torturami, okaleczeniem lub mordowaniem ofiar. Zarówno historycy, jak i świadkowie epoki podkreślają, że gwałcone były także dziewczynki, kobiety ciężarne i kobiety w podeszłym wieku?

\footnotetext{
${ }^{6}$ Postępuję tu - przy zachowaniu wszelkich różnic - za wzorem Fritza Schützego, łączącego wymogi jakościowej analizy tekstowej z krytyczną analizą kolektywnej tożsamości własnej grupy etnicznej (Schütze 1989, 1992).

7 Szereg informacji na temat masowych gwałtów na kobietach niemieckich pod koniec wojny odnaleźć można w obu wspomnianych dokumentacjach (Die Vertreibung 1984; Vertreibung 1989), a także w: Duerr 1993, s. 413-427. Warto tu na marginesie dodać, że omawiane wydarzenia są - obok wielu innych - argumentem w obszernej polemice Hansa Petera Duerra, etnologa i teoretyka kultury, z koncepcjami cywilizacyjnego postępu. Polemikę tę zawarł Duerr w swym wielotomowym dziele Mit procesu cywilizacyjnego. Wspomniany fragment pochodzi z tomu trzeciego Obsceniczność i przemoc.
} 
Dodatkową zagadkę stanowiła pewna niespójność w wywiadzie pani Zofii. Niewątpliwa wiedza narratorki o losie cywilnej ludności niemieckiej i kilkakrotnie wyrażane przez narratorkę współczucie dla ofiar nie powstrzymuje jej od sformułowania przytoczonego na wstępie obrazu mazurskich (niemieckich) kobiet. Pojawia się zatem pytanie: dlaczego w tym właśnie miejscu wywiadu zawodzi współczucie? Dodajmy, że tego rodzaju nieciągłość nie przeczy pojęciu uprzedzenia w podejściu retorycznym. Zgodnie z tym podejściem uprzedzenia nie są trwałymi strukturami psychicznymi na poziomie jednostki, odzwierciedlającymi się mechanicznie - niezależnie od kontekstu - w wypowiedziach danej osoby, lecz strukturami dyskursowymi, które mogą pojawiać się w wypowiedziach różnych osób, także tych, które gotowi jesteśmy słusznie uznać za pozbawione psychologicznie rozumianej niechęci wobec innych grup etnicznych. O pojawianiu się elementów „zatrutego języka” w postaci uprzedzeniowych struktur dyskursowych w określonych miejscach wypowiedzi lub w pewnych sytuacjach społecznych decydują ponadjednostkowe reguły komunikowania się, dostępne analizie dyskursu oraz objaśnieniu socjologicznemu i psychospołecznemu. Poniżej będę się starał wskazać na mechanizmy tekstowe, socjologiczne i psychospołeczne, które mogłyby wyjaśnić wspomnianą niespójność w narracji pani Zofii.

\section{Kontekst polityczny}

Przez wiele lat pamięć o terrorze radzieckim wobec cywilnej ludności niemieckiej oraz o ciemnych stronach postępowania strony polskiej wobec wypędzonych kultywowana była przede wszystkim przez środowiska tzw. „,wypędzonych” w Niemczech i łączyła się nierzadko z silnymi antyrosyjskimi i antypolskimi resentymentami. W tej jednostronnej wersji historii brakowało między innymi uwzględnienia istotnej okoliczności, iż niewątpliwy terror i bezprawie, jakie spotkały cywilną ludność niemiecką, były przynajmniej w części niekontrolowaną reakcją żołnierzy radzieckich i ludności polskiej na zbrodnie hitlerowskie dokonane na obydwu okupowanych społeczeństwach. Z kolei „ciemne” aspekty ofensywy radzieckiej były przemilczane przez komunistyczną propagandę oraz historiografię tzw. minionego okresu, które kładły nacisk na bezsporny heroizm Armii Radzieckiej w zwycięskiej walce $\mathrm{z}$ hitlerowskim faszyzmem oraz na ciężar strat, jakimi to zwycięstwo zostało okupione. W Polsce do niedawna społeczną amnezją objęte było szabrownictwo, zwłaszcza w odniesieniu do późniejszej fazy tego zjawiska, gdy było ono integralnie powiązane z funkcjonowaniem legalnego aparatu państwa polskiego na tzw. Ziemiach Odzyskanych.

Ślady jednostronnych wersji historii sięgają do dnia dzisiejszego, czego świadectwem były kontrowersje wokół obchodów pięćdziesięciolecia zakończenia II wojny światowej. Terror radziecki wobec ludności niemieckiej posłużył części ugrupowań prawicowych w Niemczech jako argument na rzecz odrzucenia interpretacji końca wojny jako wyzwolenia. Dodać trzeba, że chodziło tu o sprzeciw 
wobec oficjalnego stanowiska władz niemieckich, w świetle którego koniec wojny przyniósł klęskę militarną Trzeciej Rzeszy i wyzwolenie Niemiec od faszyzmu - czynniki niezbędne dla budowy demokratycznego państwa niemieckiego. Natomiast ambasador Rosji w Niemczech w radiowej wypowiedzi u progu obchodów rocznicy zakończenia wojny stwierdził, iż w Rosji nie ma zrozumienia dla niemieckiego sporu o interpretację zakończenia wojny jako wyzwolenia bądź jako klęski. „Nam wydaje się kryształowo jasne, że rozbicie faszyzmu uwolniło Niemców od najgorszego ucisku" - powiedział i nie ustosunkował się do ciemnych stron ofensywy radzieckiej. W okresie obchodów rocznicowych w polskiej prasie pojawiły się artykuły „odkłamujące” wyidealizowany obraz postępowania strony polskiej wobec wypędzonych. Warto zauważyć, że wspomniane tu spory o interpretację zakończenia II wojny światowej nadawałyby się do analizy w kategoriach unieważniania „cudzych” i uważniania „własnych” problemów w dyskursie publicznym? 9

\section{Analiza przypadku}

Dostępne materiały biograficzne na temat wzajemnego postrzegania repatriantów i wypędzonych są jedynie w ograniczonym stopniu porównywalne. Wizerunek Polaków (w tym repatriantów) w oczach reprezentantów grupy wypędzonych jest jednym z głównych wątków obszernych dokumentacji niemieckich (Die Vertreibung 1984; Vertreibung 1989). Po stronie polskiej brak jest do tej pory porównywalnego zbioru danych. Doświadczenia wojenne repatriantów były objęte w okresie PRL częściową cenzurą. W obiegu powszechnym dominował idylliczno-humorystyczny obraz losów filmowych postaci Kargula i Pawlaka ${ }^{10}$. Luka ta jest wypełniana dopiero od niedawna. Istotne miejsce $w$ tych przedsięwzięciach zajmują wywiady narracyjne zebrane w ramach projektu badawczego Biografia a tożsamość narodowa (te spośród nich, które przeprowadzone zostały z repatriantami), a także korpus wywiadów narracyjnych zebranych przez Kaję Kaźmierską dla celów przygotowanej przez nią pracy doktorskiej na temat wojennych i powojennych doświadczeń osób pochodzących z Wileńszczyzny (Kaźmierska 1996).

Należy zaznaczyć, że wizerunek wypędzonych w materiałach biograficznych pochodzących od repatriantów pojawia się rzadko i jest względnie ubogi, co samo w sobie jest istotną informacją i może świadczyć o dużym stopniu „przesłonięcia” (Ausblendung) obszaru kontaktów z wypędzonymi w polskim doświadczeniu biograficznym. Analiza wywiadu pani Zofii może być zatem traktowana wyłącznie jako przyczynek do refleksji na temat stosunku repatriantów do wypędzonych.

8 Cyt. za: „Frankfurter Rundschau”, 6 maja 1995.

9 Kategorie pojęciowe „unieważniania” i „uważniania” oraz szereg zastosowań empirycznych zawiera praca zbiorowa M. Czyżewskiego, K. Dunin i A. Piotrowskiego (1991).

${ }^{10}$ Chodzi o bohaterów popularnej komedii filmowej Sami swoi w reżyserii Sylwestra Chęcińskiego. 
Powracam do analizy omówionego na wstępie fragmentu wywiadu pani Zofii, uwzględniając - w dwóch krokach - jego bezpośrednie otoczenie tekstowe. Negatywny obraz mazurskich kobiet pojawia się bowiem w obrębie komentarza dotyczącego całościowej charakterystyki tej grupy (19:25-20:01), z kolei komentarz ten następuje po fragmencie opowiadania na temat wizyty narratorki u lekarza (18:34-19:25).

\section{Analiza komentarza na temat mazurskich kobiet (19:25-20:01)}

Na uwagę zasługuje zdanie otwierające komentarz: „I te Niem/ te Mazurki i Niemki/ no bo to właśnie tak trudno było mm prawda yy/ one właściwie się jednoznacznie nie opowiadały y" (19:25-27). Konstrukcja zdania urywa się tu trzykrotnie (co oznaczone jest znakiem ,/"). Najpierw przerwana zostaje kategoryzacja „Niemki” (,te Niem/”). Następnie dochodzi do tzw. autokorekty: niewypowiedziana uprzednio do końca kategoryzacja zostaje uzupełniona o „Mazurki” i sformułowana jako struktura dwuelementowa (,te Mazurki i Niemki/”). Konstrukcja zdania zostaje ponownie przerwana, nie dochodzi do opisu czynności lub usytuowania „Mazurek i Niemek”. Zamiast tego pani Zofia podnosi temat ówczesnych trudności w kategoryzacji kobiet mazurskich - jako sytuacyjne wytłumaczenie uprzednich dwóch przypadków zerwania konstrukcji zdaniowej: „no bo to właśnie tak trudno było mm prawda yy/". Po ponownym zerwaniu konstrukcji zdaniowej p. Zofia dostarcza wytłumaczenia trudności w kategoryzacji: trudności te miałyby być rezultatem niejasnej własnej identyfikacji etnicznej mazurskich kobiet: „one właściwie się jednoznacznie nie opowiadały y”.

W ten oto sposób tematem wypowiedzi staje się niejasna identyfikacja etniczna mazurskich kobiet. Przypisany mazurskim kobietom brak zdecydowania jest tu przedstawiony neutralnie - nie jest przedmiotem oceny narratorki. Stopienie się dwóch kategoryzacji (Mazurki i Niemki) jest skądinąd powodem, dla którego później sformułowane (a cytowane na wstępie) negatywne cechy przypisane zostają Niemkom (19:30-32 i 19:33-20:01).

Częściowa identyfikacja Mazurek z Niemkami może wskazywać także na niejawne powiązanie wypowiedzi z zagadnieniem trajektorii kolektywnej Polaków jako ofiar agresji i okupacji niemieckiej. Ponadto określanie Mazurek mianem Niemek - w obliczu polskich doświadczeń wojennych - może być samo w sobie degradujące. Można sformułować hipotezę, że trudności w kategoryzacji mazurskich kobiet mogą być elementem wskazującym na „umotywowany” charakter późniejszej uprzedzeniowej wypowiedzi, czyli na możliwość powiązania uprzedzenia $\mathrm{z}$ określoną wewnętrzną funkcją w komunikacyjnym systemie orientacji narratorki.

Kolejną częścią komentarza są uwagi na temat bezprawia. Narratorka mówiąc o okresie bezpośrednio po wojnie stwierdza: „Poza tym to nie przyszła taka Polska, zaczęło się bezprawie" (19:27). W domyśle - zwycięska armia radziecka i jej reprezentanci (aparat UB) stali ponad prawem, a nowa rzeczywistość nie 
odpowiadała wyobrażeniu narratorki o tym, czym Polska być powinna. Bezprawie komunistycznej władzy było powodem tego, że - jak mówi narratorka - „i właśnie straciliśmy bardzo dużo ludzi” (19:27-28), to znaczy, że początkowo niezdecydowani Mazurzy nie opowiadali się na rzecz polskości i wyjeżdżali z Polski - do tego ostatniego wątku narratorka wraca w zakończeniu wywiadu („Polska Ludowa pomogła stracić i Mazurów i Ślązaków” - 25:25 i nast.). Następuje objaśnienie przebiegu wypadków poprzez odwołanie się do wewnętrznych, pozytywnych cech Mazurów (Niemców): „Dlatego, że to są ludzie, którzy mają przepisy prawne zakodowane prawie genetycznie" (19:28-29), w czym objawia się element pozytywnego stereotypu Niemców. Ta wewnętrzna dyspozycja skontrastowana zostaje z obrazem nienazwanej z imienia, negatywnie postrzeganej, nowej polskiej rzeczywistości: „Natomiast tutaj właśnie nie było poszanowania prawa" (19:29).

Właśnie jako kontynuacja tematu niezdecydowania Mazurów w kwestii etnicznej tożsamości pojawia się negatywna charakterystyka seksualnej uległości mazurskich kobiet, którą przytaczam na początku. Wewnętrzna analiza tych wypowiedzi była zamieszczona na wstępie artykułu. Na podstawie kontekstu można teraz dodać, że cecha niezdecydowania - neutralna w odniesieniu do identyfikacji etnicznej - zyskuje konotację negatywną w odniesieniu do sfery uległości kobiet wobec mężczyzn. Co więcej, pomiędzy dwoma cytowanymi fragmentami negatywnej wypowiedzi o seksualnej uległości Mazurek zostaje jawnie sformułowane pozytywne określenie własnej tożsamości grupowej w kategoriach moralnej jednoznaczności, a zarazem braku seksualnej uległości: „A yy to po prostu/ no nie wiem no Polki były harde, Polki były twarde. No w każdym razie mówię o swoim pokoleniu. To ja sobie no nie wyobrażałam takich rzeczy" (19:32-33). Na uwagę zasługuje synergiczny, trójskładnikowy charakter własnej tożsamości grupowej: etniczność, płeć i pokolenie.

Istotny element omawianej wypowiedzi może świadczyć o jej uprzedzeniowym charakterze: pozytywne odróżnianie własnej grupy od innej grupy jest jedną z podstawowych potencjalnych cech języka uprzedzeń (,dyskurs My” - Wodak i in. 1990; „pozytywna autoprezentacja” - van Dijk 1993). Zwróćmy uwagę, iż w relacji pani Zofii nieusprawiedliwiona uległość seksualna oznacza zaprzeczenie moralnej ,zacności” (pojęcie George'a Mosse), czyli norm określających mieszczańską obyczajowość. Zarzut braku mieszczańskiej „zacności” jest w koncepcji Mosse (1987) podstawowym wymiarem uprzedzeń rasowych i antysemityzmu w tradycji europejskiej, a tym samym stanowi jedno z ważniejszych kryteriów wykluczania z moralnej wspólnoty. Ponadto wykroczenia przeciw mieszczańskim normom seksualnej obyczajowości są w koncepcji George'a Mosse niemal paradygmatycznym sposobem złamania zasad „zacności”, a tym samym jednym z najbardziej wyrazistych składników uprzedzenia. Normatywny wątek wypowiedzi pani Zofii wskazuje zatem na możliwość silnego społeczno-kulturowego „umotywowania" uprzedzeniowej struktury. 


\section{Analiza fragmentu narracyjnego na temat wizyty u lekarza (18:34-19:25)}

Fragment narracyjny (18:34-19:25) dotyczy badań lekarskich, jakim musiała się poddać narratorka po przyjęciu do pracy. Właśnie w kolejce do lekarza narratorka widzi wielką liczbę mazurskich kobiet. Przypadkowo spotkany kolega jest zaskoczony, widząc narratorkę w poczekalni lekarskiej i wyjaśnia jej, że Mazurki są chore wenerycznie:

To są wszystkie te Mazurki chore wenerycznie, które tak straszliwie/ bo przecież gwałcili wszystkie i stare i młode i ma/ i dziewczynki małe i to są wszystko do lekarza wenerycznie chore kobiety które stoją po prostu w kolejce żeby się leczyć (19:6-9).

Przyczyna choroby zostaje sformułowana dopiero po pierwszym zerwaniu konstrukcji zdaniowej („,które tak straszliwie/) - w ramach dygresji, po której narratorka podejmuje uprzednią konstrukcję zdaniową (,i to są wszystko”). Tak więc narratorka przerwała odtwarzanie wypowiedzi swego kolegi, by uczynić swoje opowiadanie zrozumiałym dla słuchacza (osoby przeprowadzającej wywiad). Za Fritzem Schütze (1982) można powiedzieć, że dygresja ta spełnia tzw. wymóg uszczegółowienia narracji (Schütze 1982) - bez podania zawartej w dygresji informacji narracja byłaby niezrozumiała. W dygresji tej brakuje jednakże informacji, kto był sprawcą gwałtów na mazurskich kobietach. Bezpośrednio po odtworzeniu całości rozmowy ze swym kolegą narratorka przerywa zatem ponownie opowiadanie i kontynuuje uszczegółowienie narracji w kolejnej dygresji: „Proszę pani straszne rzeczy tam się działy, straszne, Ruscy gwałcili absolutnie wszystkie" (19:10). Obydwie dygresje pełnią istotną dodatkową funkcję: dają narratorce sposobność do podkreślenia bezwzględności żołnierzy radzieckich. Można tu odnaleźć pewne cechy języka uprzedzeń wobec Rosjan: pejoratywne określenie „Ruscy” i akcentowane uogólnienie „absolutnie wszystkie”.

Narratorka jest jedyną pacjentką należącą do innej kategorii społecznej (jej badanie lekarskie związane jest z przyjęciem do pracy). Kolega wprowadza ją do lekarza bez kolejki. Żarty lekarza wyprowadzają narratorkę z równowagi. Podkreśla, iż lekarz powiedział: „Czemu się pani tak niepokoi [...] Nie, to panią nie dotyczy" (19:20 i 19:23) - chodzi przypuszczalnie o badanie ginekologiczne, a w konsekwencji o ewentualne podejrzenie choroby wenerycznej, która - jak wiadomo - jest silnym ,symbolem stygmatu” (por. Goffman 1963).

Dopiero w kontekście tej narracji, jako jej teoretyczne opracowanie, pojawia się omówiony uprzednio pejoratywny komentarz na temat mazurskich kobiet. Negatywnie oceniane zachowanie innej grupy (seksualna uległość mazurskich kobiet) jest zatem tłumaczone - przynajmniej częściowo - jako wynik wewnętrznych cech grupy etnicznej, a nie jako rezultat zewnętrznych, narzuconych okoliczności. Potwierdza się tu zasada znana z teorii atrybucji: stereotypy i uprzedzenia pozwalają na tłumaczenie ,win” grupy cudzej poprzez przypisanie jej członkom negatywnych dyspozycji wewnętrznych (Hewstone, Klink 1994). 
Uderzający jest brak uwzględnienia przedstawionych w dygresji zewnętrznych okoliczności (masowe gwałty i związane z tym upodlenie i upokorzenie mazurskich kobiet) przy późniejszym tłumaczeniu seksualnej uległości Mazurek w ramach komentarza, to znaczy zdania sprawy z tego, że ewentualna uległość seksualna kobiet nie musiała być negatywną dyspozycją wewnętrzną, lecz mogła być rezultatem negatywnych zewnętrznych okoliczności (doświadczenia masowych gwałtów) i próbą ich uniknięcia w przyszłości poprzez zapewnienie sobie bezpieczeństwa. Tego rodzaju usprawiedliwiające rozumowanie mogłoby zapobiec uprzedzeniu opartemu na wewnętrznej, negatywnej atrybucji. W myśl teorii atrybucji tłumaczenie negatywnie ocenianych zachowań własnych lub własnej grupy polega z reguły na odwołaniu się do zewnętrznych okoliczności (Hewstone, Klink 1994). Dodajmy, że we wspomnieniach wypędzonych kobiet pojawiają się - skądinąd nieliczne - uwagi o tym, że pełnienie roli domowej krawcowej i gospodyni u radzieckich oficerów dawało kobietom gwarancję bezpieczeństwa. W relacjach tych nie ma jednak mowy o usługach seksualnych na rzecz radzieckich oficerów lub polskich ubowców, co może być wynikiem „przesłonięcia”.

Zauważmy, iż w omawianych wypowiedziach pani Zofii występuje także brak nasuwającego się logicznego powiązania dwóch okoliczności - masowych gwałtów na Mazurkach i ich seksualnej uległości. Tego rodzaju luka w rozumowaniu jest cechą mogącą wskazywać na uprzedzeniowy charakter wypowiedzi ${ }^{11}$. Dodajmy, że o ile pojawienie się dygresji w toku narracji spełniało jeden z wymogów organizacji narracyjnej (wymóg uszczegółowienia), o tyle brak odniesienia do tej dygresji w toku późniejszej argumentacji (w obrębie komentarza) świadczy o niespełnieniu jednego z wymogów organizacji argumentacyjnej, wymogu uwzględniania i rozważania ${ }^{12}$.

Uwzględniając całościową analizę segmentu, na który składają się narracyjny fragment na temat wizyty u lekarza oraz komentarz na temat mazurskich kobiet (granice segmentu - 18:34-20:01) można wskazać jeszcze jeden mechanizm „motywujący” pojawienie się struktur uprzedzeniowych. O ile bowiem komentarz dotyczył całościowo pojmowanych grup (zagadnienie powszechnie znanego stygmatu, a zatem stygmatu w wymiarze grupowej „tożsamości społecznej”, a tym samym zagadnienie społecznej identyfikacji - w sensie Goffmanowskim, 1963), o tyle fragment narracyjny dotyczy osobistych doświadczeń narratorki. Narratorka opowiada, jak doszło do tego, że ona osobiście nie została uznana za osobę posiadająca stygmat (uniknięcie stygmatyzacji w wymiarze „tożsamości osobistej”, tym samym zagadnienie identyfikacji osobistej - w sensie Goffmanowskim 1963).

${ }^{11}$ Odnoszę się tu do nie opublikowanej koncepcji argumentacyjnej struktury uprzedzenia autorstwa Fritza Schützego.

${ }^{12}$ Kategorie wymogów organizacji narracyjnej i organizacji argumentacyjnej stosowane są w metodzie biograficznej Fritza Schützego. 


\section{Inne fragmenty wywiadu}

Sięgając nieco wstecz w narracji p. Zofii napotykamy jeszcze jedną, analogiczną relację. Pani Zofia opowiada o bestialskim traktowaniu Mazurów na dworcu kolejowym przez „Ruskich” i „ubowców” (wyrywanie bagażu z rąk, wyrzucenie zmarłego dziecka przez okno, 17:25-17:37 oraz 18:7-9). Istotne wydaje się to, iż w tym miejscu użyte zostaje - pośrednio - etniczne przyporządkowanie ubowców („nasze UB”), skądinąd bez użycia kategorii „Polacy”. Warto zauważyć także, że właśnie w tym kontekście narratorka sygnalizuje współczucie dla Mazurów i Warmiaków (,moje wrażenia z tej straszliwej sytuacji, jak spotkała Mazurów i Warmiaków", 17:26-27). W toku tej relacji występuje ponadto - analogiczny jak w omówionym uprzednio komentarzu o mazurskich kobietach, gdzie była mowa o „ludziach, którzy mają przepisy prawne zakodowane prawie genetycznie (19:28-29) - element pozytywnego obrazu Mazurów (Niemców). Otóż w ramy relacji na temat bestialskiego traktowania Mazurów na dworcu p. Zofia wprowadza zdanie komentarza, w którym pewien wymiar zacności poddany zostaje etnicznej dystrybucji, w postaci pozytywnego stereotypu Mazurów (Niemców): „Oni mieli yy Niemcy i w ogóle wszyscy y którzy prawda pod ich rządami byli, byli przyzwyczajeni do takiego ładu, do porządku" (17:37-18:2 - ta ogólna uwaga ma tłumaczyć sposób, w jaki Mazurzy spakowali swój bagaż). Interesujące jest to, że w obydwu wypadkach obraz pozytywny odnosi się do grup pojmowanych całościowo, przy czym realizacja językowa wymaga tu rodzaju męskiego („oni”).

Wznowiona dramatyczna relacja narracyjna na temat wydarzeń na dworcu („to, to, to im zabierano” - 18:2-3, chodzi o bagaż Mazurów, zabierany przez żołnierzy radzieckich i polskich ubowców) urywa się ponownie, gdyż dochodzi do uzupełniającego komentarza, w którym narratorka przedstawia wyrazisty, pejoratywny obraz polskich szabrowników: „Było mnóstwo polskich szabrowników, obrzydliwe hieny, które z centralnej Polski przyjeżdżały" (18:3-4). Polscy szabrownicy bez wątpienia przeczyli „,zacności”: „dokonywali po prostu zwyczajnych kradzieży, rabunków ii iii i jeszcze rzeczy gorszych zapewne" (18:6-7). Narratorka podkreśla jednak, że szabrownicy nie byli repatriantami, lecz pochodzili z centralnej Polski, a ponadto stanowili „element” (18:5). Tak więc zarówno szabrownicy, jak i ubowcy, aczkolwiek byli Polakami, to - w rozumieniu narratorki - nie reprezentowali Polski.

Porównanie wizerunku Mazurów w obrębie relacji dotyczącej wydarzeń na dworcu i w obrębie relacji dotyczącej wizyty u lekarza prowadzi do obserwacji zgodnej z niektórymi ustaleniami psychologii społecznej na temat czynników poznawczych sprzyjających lub utrudniających komunikowanie uprzedzeń. Według koncepcji schematów „Ja” i „My”, opracowanej przez Marię Jarymowicz (1992), aktualizacja schematu „My” (w relacji dotyczącej wizyty u lekarza - „My młode Polki”) prowadzić może do wzmożonej stereotypizacji postrzegania grup, a także do faworyzowania swoich (pozytywny obraz polskich kobiet) bądź defaworyzowania obcych (negatywny obraz mazurskich kobiet). Według koncepcji 
odnoszącej się do wpływu zakłóceń własnej tożsamości narodowej na stereotypizację oglądu grup mniejszościowych, opracowanej przez Ewę Trzebińską (1992), naruszenie doświadczanej tożsamości narodowej (w relacji dotyczącej wydarzeń na dworcu „,nasze UB” oraz „polscy szabrownicy” są podmiotami działań krzywdzących grupę mniejszościową Mazurów) może prowadzić do ustosunkowania się do reprezentantów grupy mniejszościowej (w tym wypadku do współczucia wobec krzywdzonej grupy mniejszościowej) bardziej pozytywnego aniżeli wówczas, gdy własna tożsamość narodowa postrzegana jest bez zakłóceń (jak to ma miejsce w relacji dotyczącej wizyty u lekarza).

Nie kwestionując wskazanych sytuacyjnych korelacji procesów poznawczych (schematy „Ja” i „My”, formy postrzegania własnej tożsamości narodowej) i pojawiania się uprzedzeń międzygrupowych zgłosić należy pytanie, czy czynniki poznawcze mogą także stanowić zmienną niezależną wobec uprzedzeń w sensie generalnej zależności genetycznej. W tym ostatnim względzie bardziej przekonujący wydaje się socjologiczny punkt widzenia, w świetle którego tradycja kulturowa i niektóre zawarte w niej normatywne modele zachowania (np. normatywny model „zacności”) mogą być uznane za jeden z czynników kształtujących struktury uprzedzeniowe i podtrzymujących ich obecność w dostępnych zasobach interpretacji.

Podsumowując i łącząc kilka wprowadzonych do analizy wątków można stwierdzić: dyskursowe ,umotywowanie” komunikowanego przez p. Zofię uprzedzenia wobec mazurskich kobiet jest związane z pozytywnym odróżnieniem własnej osoby jako osoby, a także własnej grupy pokoleniowo-etnicznej jako spełniających wymogi ,zacności” od pejoratywnie definiowanej innej grupy pokoleniowo-etnicznej, która zostaje wykluczona z moralnej wspólnoty poprzez odmowę ,zacności” w sferze seksualnej. Podkreślić należy ambiwalentny charakter wizerunku Mazurów - uprzedzenie dotyczy seksualnej uległości kobiet, jednocześnie pozytywnie oceniane jest poszanowanie prawa i porządku przez Mazurów (Niemców), należące również do sfery „zacności”.

Pozornie słabo „umotywowane" uprzedzenie okazało się więc zarówno indywidualnie, jak i grupowo wielostronnie „umotywowane”. Podkreślmy ponownie, że nie chodzi tu o - skądinąd możliwą - psychologiczną motywację narratorki, lecz o motywację dyskursową, czyli o podatne na analizę interpretatywną związki tekstowe oraz o mechanizmy socjologiczne i psychospołeczne.

W uzupełnieniu dodajmy, że obraz Mazurów w wywiadzie p. Zofii nie przeczy ogólnemu obrazowi Niemców w Polsce w latach powojennych, do którego należały takie cechy jak potulność, a nawet służalczość Niemców na tzw. terenach odzyskanych oraz prostytucja Niemek na terenie Niemiec - cechy postrzegane przez Polaków w okresie powojennym ze szczególnym sarkazmem (Dmitrów 1991: 198). 


\section{Zakończenie}

Kończąc chcę sformułować następującą hipotezę: dostrzeżenie w innej grupie ofiary przemocy, dojrzenie cudzej trajektorii (a tym samym przyjęcie punktu widzenia Innego, czyli stosowanie przekładalności perspektyw - w sensie nadanym temu terminowi przez Alfreda Schütza 1979) - jest czynnikiem, który może uodparniać na uprzedzenia. Hipotezę tę można ujmować psychologicznie, ale można także odnosić ją do zjawisk dyskursowych (w przypadku omawianego segmentu: do tego, o czym się, co prawda, opowiada, lecz czego nie uwzględnia się w argumentacji, popadając w struktury języka uprzedzeń). Tak czy inaczej, tego właśnie czynnika do pewnego stopnia zabrakło w omawianym fragmencie relacji pani Zofii o mazurskich kobietach.

Na podstawie całości wywiadu wskazać należy na szersze uwarunkowania biograficzne: narratorka była w owym czasie młodą osobą, zidentyfikowaną ze swoją kulturą (przedwojenna Polska widziana przez pryzmat Kresów). Wymuszona przez okoliczności „repatriacja” była dla niej zapewne pierwszym głębokim i jednocześnie traumatycznym - doświadczeniem międzykulturowym. Spotkanie z nową rzeczywistością było przypuszczalnie w dużym stopniu zaprogramowane przez wymiar zestawiania nowych doświadczeń z pozytywnym obrazem utraconego świata.

Podkreślmy raz jeszcze, że w relacji pani Zofii nie występuje całkowite „przesłonięcie” cudzej trajektorii. Narratorka rejestruje przecież kolektywną trajektorię Mazurów (Niemców) na terenie Mazur bezpośrednio po zakończeniu wojny i sygnalizuje swoje z nią współczucie - ale mimo to komunikuje uprzedzenie. Tym samym potwierdza się źródłowy sens terminu ,uprzedzenie": uprzedzenie ma niewiele wspólnego z własnym doświadczeniem biograficznym, związanym z grupą, której dotyczy - w tym sensie, że uprzedzenie (prejudice, Vorurteil) poprzedza konkretne doświadczenie.

\section{Bibliografia}

Adorno T. W. i in., 1950, The Authoritarian Personality, Harper and Row, New York.

Allport G., W., 1954, The Nature of Prejudice, Anchor Books, Garden City.

Bar-Tal D. i in. (red), 1989, Stereotyping and Prejudice. Changing Conceptions, Springer, New York.

Billig M. i in., 1988, Ideological Dilemmas. A Social Psychology of Everyday Thinking, Sage, London.

Billig M., 1991, Ideology and Opinions. Studies in Rhetorical Psychology, Sage, Newbury Park, CA. 
Czyżewski M., 1995, Trajektoria i uprzedzenie (nieopublikowane opracowanie indywidualne w ramach raportu końcowego projektu KBN Biografia a tożsamość narodowa).

Czyżewski M., Dunin K., Piotrowski A. (red.), 1991, Cudze problemy: O ważności tego, co nieważne, OBS, Warszawa.

Die Vertreibung der deutschen Bevölkerung aus den Gebieten östlich der Oder-Neisse, 3 t., 1984, (łącznie t. 1 w wielotomowej Dokumentation der Vertreibung der Deutschen aus Ost-Mitteleuropa), DTV, München.

Duerr H. P., 1993, Obszönität und Gewalt, t. 3, [w:] Der Mythos vom Zivilisationsprozess, Frankfurt am Main, Suhrkamp.

Dmitrów E., 1991, Obraz Niemców w Polsce w latach 1945-1948, [w:] W. Wrzesiński (red.), Wokót stereotypów Polaków i Niemców, Wydawnictwo Uniwersytetu Wrocławskiego, Wrocław, s. 185-209.

Goffman E., 1968, Stigma: Notes on the Management of Spoiled Identity, Penguin, Harmondsworth.

Hewstone M., Klink A., 1994, Intergruppenattribution, [w:] F. Försterling, J. Stiensmeier-Pelster (red.), Attributionstheorie. Grundlagen und Anwendungen, Hogrefe, Göttingen.

Jarymowicz M., 1992, Schematy JA, MY a uprzedzenia międzygrupowe, [w:] Z. Chlewiński, I. Kurcz (red.), Stereotypy i uprzedzenia, „Kolokwia Psychologiczne”, t. 1, Instytut Psychologii PAN, Warszawa, s. 45-56.

Kaźmierska K., 1996, Doświadczenia wojenne Polaków a ksztattowanie tożsamości etnicznej, Praca doktorska (maszynopis), Instytut Socjologi UŁ, Łodź.

Mosse G. L., 1987, Nationalismus und Sexualität. Bürgerliche Moral und sexuelle Normen, Rowohlt, Reinbek.

Schütz A., 1979, Potoczna i naukowa interpretacja ludzkiego działania, „Studia Filozoficzne", nr 6, s. 22-54.

Schütze F., 1981, Prozessstrukturen des Lebensablaufs, [w:] J. Matthes, M. Pfeifenberger, M. Stosberg (red.), Biographie in handlungswissenschaftlicher Perspektive, Verlag der Nürnberger Forschungsvereinigung, Nürnberg, s. $67-156$.

Schütze F., 1982, Narrative Repräsentation kollektiver Schicksalbetroffenheit, [w:] E. Lämmert (red.), Erzählforschung, Metzler, Stuttgart, s. 568-590.

Schütze F., 1989, Kollektive Verlaufskurve oder kollektiver Wandlungsprozess. Dimensionen des Vergleichs von Kriegserfahrungen amerikanischer und deutscher Soldaten im Zweiten Weltkrieg, „Bios. Zeitschrift für Biographieforschung und Oral History", z. 1, s. 31-110.

Schütze F., 1992, Pressure and Guilt: War Experiences of a Young German Soldier and their Biographical Implications (Part 1), „International Sociology” 7(2), s. 187-208. 
Schütze F., 1992, Pressure and Guilt: War Experiences of a Young German Soldier and Their Biographical Implications (Part 2), „International Sociology” 7(3), s. 347-367.

Stroebe W., Insko C. A., 1989, Stereotype, Prejudice and Discrimination: Changing Conceptions in Theory and Research, [w:] Bar-Tal i in. (red.), Stereotyping and Prejudice. Changing Conceptions, Springer, New York.

Tajfel H., 1982, Gruppenkonflikt und Vorurteil. Enstehung und Funktion sozialer Stereotypen, Huber, Bern.

Trzebińska E., 1992, Zaangażowanie własnej tożsamości narodowej jako czynnik modyfikujący ustosunkowania wobec przedstawicieli grup mniejszościowych, [w:] Z. Chlewiński, I. Kurcz (red.), Stereotypy i uprzedzenia, „Kolokwia Psychologiczne", t. 1, Instytut Psychologii PAN, Warszawa, s. 57-66.

van Dijk, Teun A., 1984, Prejudice in Discourse, Benjamins, Amsterdam.

van Dijk, Teun A., 1992, Discourse and the Denial of Racism, „Discourse and Society", t. 3, s. 87-118.

van Dijk, Teun A., 1993, Elite Discourse and Racism, Sage, Newbury Park, CA. Vertreibung und Vertreibungsverbrechen 1945-1948. Bericht des Bundesarchivs vom 28. Mai 1974. Archivalien und ausgewählte Erlebnisberichte, 1989, Kulturstiftung der deutschen Vertriebenen, Bonn.

Wejland A. P., 1991, Obrazy grup spotecznych. Studium metodologiczne, Instytut Filozofii i Socjologii PAN, Warszawa.

Wodak R. i in., 1990, ,, Wir sind alle unschuldige Täter”. Diskursanalytische Studien zum Nachkriegsantisemitismus, Suhrkamp, Frankfurt am Main.

Wodak R. i in., 1994, Die Sprachen der Vergangenheit. Öffentliches Gedenken in österreichischen und deutschen Medien, Suhrkamp, Frankfurt am Main. 